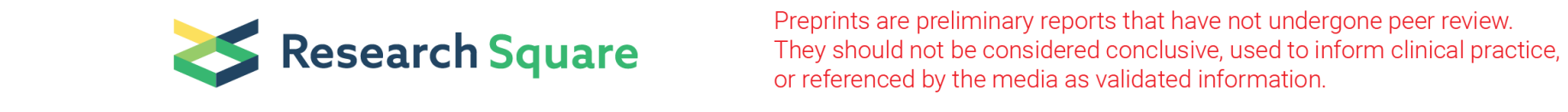

\title{
Landslide Susceptibility Zonation Using Geospatial Technologies and Multi Criteria Evaluation Techniques in Upper Didessa Sub-basin, Southwest Ethiopia
}

\author{
Redwan Sultan Mohammednur \\ Jimma Zone Land Administration and Use office \\ Dessalegn Obsi Gemeda ( $\nabla$ dasoobsi@gmail.com ) \\ Jimma University College of Agriculture and Veterinary Medicine https://orcid.org/0000-0002-8635-260X \\ Kiros Tsegay Deribew \\ Raya University
}

\section{Research}

Keywords: Analytical hierarchy process, Landslide, Multi-criteria evaluation, Weighted linear combination

Posted Date: December 28th, 2020

DOI: https://doi.org/10.21203/rs.3.rs-121667/v1

License: (c) (i) This work is licensed under a Creative Commons Attribution 4.0 International License. Read Full License 


\section{Abstract}

Landslide is a serious geo-hazard that poses destruction and loses of life in different part of the world. The severity of the problem is higher in developing countries like Ethiopia. This study is aimed at assessing the spatial landslide susceptibility in the upper Didessa sub-basin using GIS and multi criteria evaluation (MCE) techniques. In order to reach this objective both primary (field survey) and secondary data (expert interview, literature, remote sensing data, digital soil map and geological map) were obtained from various source. Eleven landslide causative factor identified in this research are slope, aspect, drainage density, topographic wetness index (TWI), stream power index (SPI), topographic ruggedness index, hypsometric integral, lithology, LULC, soil texture, and distance from road. The analytical hierarchy process (AHP) method was employed to identify the weight of each indicator from the pairwise comparison matrix. The weighted linear combination was then used to generate landslide susceptibility map (LSM). Based on landslide susceptibility, the study area was classified into very high, high, moderate, low, and very low susceptibility zones. Finally, based on the elevenlandslide causative factor analysis, about $24 \%$ of the study area is moderately susceptible, while $12 \%$ and $6 \%$ were classified as high and very high susceptibility to landslides, respectively. The results of this study could help decision makers for future landslide hazardous preventions and mitigation strategies.

\section{Background}

Landslide is occurred when the bulk of soils separated from its original location and moved to down the hills. Landslides are common natural hazardous occurred worldwide and results in considerable economic loss, life causalities and adverse impacts on infrastructure and environment (Lombardo et al., 2020; Bragagnolo et al., 2020; Zhu et al., 2018; Hamza and Raghuvanshi, 2017; Shahabi and Hashim, 2015; Feizizadeh et al., 2014). The problem of landslide is occurring in all continents and countries with high severity in mountains regions (Youssef and Pourghasemi, 2020; Basu and Pal, 2018; Raghuvanshi et al., 2015). Landslide susceptibility assessment and zonation is a crucial tool to minimize and control landslide disasters (Chen and Chen,2021; Chen and Li, 2020). Landslide assessment can provide important information to recognize and predict the location of future landslides (Chen and Li, 2020) that can support hazardous monitoring and mitigation (Chen and Li, 2020; Demir, 2019; Feizizadeh et al., 2014; Solaimani et al., 2013). Landslide susceptibility Mapping (LSM) and zonation need to be identified for potential landslide identification for mitigation strategies (Feizizadeh et al., 2014; Feizizadeh and Blaschke, 2013).

So far, different scholars used various factors for landslide susceptibility mapping, for instance, Youssef and Pourghasemi (2020) used eleven factors "Lithology, lineaments, geomorphology, soil type and depth, slope angle, slope aspect, curvature, altitude, engineering properties of the lithological material, land use patterns, and drainage networks". Others study by Othman et al. (2012) used ten parameters namely "Slope, lithology, soil properties, geomorphology, land use, aspect, elevation, rainfall, proximity to road, and proximity to the river". Youssef and Pourghasemi (2020) used a total of twelve parameters for landslide susceptibility mapping in Saudi Arabia recently. Other studies by Chen and Li (2020); Shahri et al. (2019); and Nicu and Asandulesei (2018) used 16, 14 and 12 factors for landslide susceptibility mapping, respectively. For the better assessment of landslides using Geographic Information System (GIS) and remote sensing, it is crucial to include varies parameters as used by various scholars in different countries (Chen and Chen,2021; Bragagnolo et al., 2020; Chen and Li, 2020; Youssef and Pourghasemi, 2020; Demir, 2019; Nepal et al., 2019; Shahri et al., 2019;Hamza and Raghuvanshi, 2017; Nicu, 2017; Raghuvanshi et al., 2015; Feizizadeh et al., 2014; Othman et al., 2012).

The use of GIS and MCE techniques have been used widely in landslides hazardous areas identification (Arca et al., 2018; Feizizadeh et al., 2014; Othman et al., 2012; Chakhar and Mousseau, 2008; Kamp et al.,2008; Carver, 1991). Even though, there is a shortage scientific information in the study area, there are various reports which indicates the severity of landslides in the study area. this study makes an attempt at assessing landslide susceptibility zonation by integrating GIS and MCE techniques. This study provides an important information to minimize the potential risks of landslides in the study area. 


\section{The Study Area}

The study area is located in Oromia National Regional State in three district of Jimma Zone under Didessa Sub basin: Goma, Gumay, and Setema south west Ethiopia. It covers $1500.39 \mathrm{Km}^{2}$, within $07^{0} 40^{\prime} 0^{\prime \prime}$ to $8^{0} 10^{\prime} 0^{\prime \prime} \mathrm{N}$ latitude and $36^{\circ} 10^{\prime}$ $3^{\prime \prime}$ to $36^{\circ} 40^{\prime} 0^{\prime \prime} \mathrm{E}$ longitude (Fig. 1). The topography of the study area is characterized as lowland plains and plateau with, some undulating to steep land forms, including depressions and valley floors. The terrain elevation ranges from $1363 \mathrm{~m}$ to $2617 \mathrm{~m}$ a.s.I. Acrisol, Luvisol, and Cambisol, Nitosol leptosol, lixisol and vertisol are the dominat soil types in the study area. The climate of the study area is cool and humid tropical climate.

\section{Methods And Materials}

Five data sources were acquired for landslide susceptibility mapping. These includes: (1) field survey, which is collected from the field with the support of Global Positioning Systems(GPS) and experts interview, (2) satellite data for LULC, slope, aspect, topographic wetness index (TWI), stream power index (SPI), topographic ruggedness index (TRI), hypsometric integral ( $\mathrm{HI}$ ) and drainage identification, (3) geological data for understanding the existing rocks and its formation in the study area (4) soil data for soil texture and (5) google earth for road network identifications.

Eleven landslide controlling factor were identified by stakeholders and literature review, which was used for landslide susceptibility mapping and zonation: slope, aspect, topographic ruggedness index and hypsometric integral, proximity to road, lithology, drainage density, TWI, and SPI, environmental factor (LULC) and soil factors (soil texture). After controlling factors identifications, new value was assigned (standardized), ranking and scoring landslide susceptibility factor in AHP matrix was performed. AHP was developed by Saaty in the 1970's (Saaty, 1977) and have been widely used in landslide susceptibility mapping (Demir, 2019; Yan et al., 2019; Nguyen and Liu, 2019; Pradhan and Kim, 2018; Nicu and Asandulesei, 2018; Ahmed, 2015; Feizizadeh et al., 2014;Torkashvand et al., 2014; Kayastha et al., 2013; Moradi et al., 2012; Othman et al., 2012). The methodology used in this study is summarized (Fig. 2).

\section{Results And Discussions}

In the present study, landslides susceptibility areas were identified and collected with the support of GPS along the periphery, and wherever, inaccessibility condition we supported with Google Earth image, then point and polygon data for were prepared as KML format which was later converted into vector (Fig. 3). Landslides near to crop land is very serious and common in the study area (Fig. 4).

The major soil texture in the study area is sandy loam, clay and clay loam accounting $37 \%, 19.84 \%$ and $17.2 \%$, respectively. Whereas, sandy clay loam and loam share about $15.54 \%$ and $10.22 \%$ of the total cover area, respectively (Table, 1). The highest landslide is occurred in sandy loam textural classes. As indicated in Sharma et al. (2012) Sandy loams have low organic matter content and easily detach and results in landslide.

Regarding landslide occurrence in each category of soil texture in the study area sandy loam accounts the greater share and is mostly distributed in the west to south western part of the study area (Fig. 5). Textural classes are distributed where past landslide is occurred i.e. sandy loam has greater influence on landslide. Moreover, sandy loam has manifested the greater share $(52 \%)$ of total landslide occurrences in $37.2 \%$ of the total study area. Study by (Maidment,1992) indicates that sandy loam has maximum value in terms of angle of friction and porosity which has a direct relation with slope instability.

\section{Assigning rank for LULC}


From the LULC, the vegetative areas are less susceptible to landslides in the areas. Vegetation can adversely influence soil stability (Subramani and Krishnan, 2015). Woldaregay (2013) also confirmed that deforestation and land degradation are the major contributing factors for landslides hazardous in Ethiopia. The maximum probability of landslide occurrence was observed in cultivated land with 9 landslide incidences out of 25, built-up is the second land use that have manifested 7 landslides, whereas, dense forest, sparse forest and grazing land showed a low probability of landslide hazard index. Thus, the incidence of landslide is inversely related to the vegetation density. Hence, built-up and barren slopes are more prone to landslide activity.

Landslide frequency is mostly found at mountainous and hilly regions (Sharma et al., 2012), where forests have been severely destroyed due to the deforestation (Mersha and Meten, 2020). About $57 \%$ of the basin is dominated by low to high density of vegetation. The cultivated land covers $15 \%$, grassland, built-up accounts $13 \%$ and $12 \%$, respectively. The remaining $4 \%$ are bare land (Table 2). In summer season, the hilly and mountainous area that have less covered vegetation and utilized for agriculture and barren land are more susceptible to landslide.

Table 1

Distribution of soil texture and landslide occurrence in the study area

\begin{tabular}{|llllll|}
\hline No & Textural class & Area in ha & Area in \% & Rank & \#landside occur \\
\hline 1 & Clay & 31235.94 & 19.84 & 2 & 3 \\
\hline 2 & Sandy loam & 58567.38 & 37.2 & 5 & 13 \\
\hline 3 & SCL & 24466.05 & 15.54 & 3 & 3 \\
\hline 4 & Clay loam & 27071.55 & 17.19 & 1 & 5 \\
\hline 5 & Loam & 16098.28 & 10.22 & 1 & 1 \\
\hline & Total & 157439.2 & 100 & & 25 \\
\hline
\end{tabular}

Table 2

Land use land cover categories' and landslide occurrences in the study area

\begin{tabular}{|llllll|}
\hline No & LULC class & Area in ha & Area (\%) & Rank & \# landslide occurrence \\
\hline 1 & Dense Forest & 61401.29 & 39 & 1 & 1 \\
\hline 2 & Sparse Forest & 26764.66 & 17 & 3 & 3 \\
\hline 3 & Cultivated land & 23615.88 & 15 & 4 & 9 \\
\hline 4 & Grass land & 20467.09 & 13 & 2 & 2 \\
\hline 5 & Built up & 18892.72 & 12 & 5 & 7 \\
\hline 6 & Barren land & 6297.56 & 4 & 5 & 4 \\
\hline & Total & 157439.2 & 100 & & 25 \\
\hline
\end{tabular}


Table 3

Pair wise comparison matrix of parameter selected for this study

\begin{tabular}{|llllllllllll|}
\hline Factors & Slope & $\begin{array}{l}\text { Drainage } \\
\text { density }\end{array}$ & SPI & $\begin{array}{l}\text { Soil } \\
\text { texture }\end{array}$ & TWI & Lithology & LULC & TRI & HI & Road & Aspect \\
\hline Slope & 1 & 2 & 2 & 2 & 2 & 3 & 3 & 4 & 5 & 5 & 6 \\
\hline $\begin{array}{l}\text { Drain. } \\
\text { density }\end{array}$ & $1 / 2$ & 1 & 2 & 2 & 2 & 3 & 3 & 4 & 5 & 5 & 6 \\
\hline SPI & $1 / 2$ & $1 / 2$ & 1 & 2 & 2 & 2 & 3 & 3 & 3 & 4 & 5 \\
\hline $\begin{array}{l}\text { Soil } \\
\text { texture }\end{array}$ & $1 / 2$ & $1 / 2$ & $1 / 2$ & 1 & 2 & 2 & 3 & 3 & 3 & 3 & 4 \\
\hline TWI & $1 / 2$ & $1 / 2$ & $1 / 2$ & $1 / 2$ & 1 & 2 & 2 & 3 & 4 & 5 & 5 \\
\hline Lithology & $1 / 3$ & $1 / 3$ & $1 / 2$ & $1 / 2$ & $1 / 2$ & 1 & 2 & 3 & 3 & 4 & 4 \\
\hline LULC & $1 / 3$ & $1 / 3$ & $1 / 3$ & $1 / 3$ & $1 / 2$ & $1 / 2$ & 1 & 2 & 3 & 3 & 4 \\
\hline TRI & $1 / 4$ & $1 / 4$ & $1 / 3$ & $1 / 3$ & $1 / 3$ & $1 / 3$ & $1 / 2$ & 1 & 2 & 3 & 3 \\
\hline HI & $1 / 5$ & $1 / 5$ & $1 / 3$ & $1 / 3$ & $1 / 4$ & $1 / 3$ & $1 / 3$ & $1 / 2$ & 1 & 3 & 4 \\
\hline Road & $1 / 5$ & $1 / 5$ & $1 / 4$ & $1 / 3$ & $1 / 5$ & $1 / 4$ & $1 / 3$ & $1 / 3$ & $1 / 3$ & 1 & 3 \\
\hline Aspect & $1 / 6$ & $1 / 6$ & $1 / 5$ & $1 / 4$ & $1 / 5$ & $1 / 4$ & $1 / 4$ & $1 / 3$ & $1 / 4$ & $1 / 3$ & 1 \\
\hline L= & 4.42 & 6.07 & 7.95 & 9.58 & 10.98 & 14.56 & 18.36 & 21.16 & 29.58 & 35.33 & 44 \\
\hline
\end{tabular}

Table 4

umax of considered parameter

\begin{tabular}{|llllllllllll|}
\hline Factors & Slope & $\begin{array}{l}\text { Drainage } \\
\text { density }\end{array}$ & SPI & $\begin{array}{l}\text { Soil } \\
\text { texture }\end{array}$ & TWI & Lithology & LULC & TRI & HI & Road & Aspect \\
\hline $\begin{array}{l}\text { Coloumn } \\
\text { totals }\end{array}$ & 4.42 & 6.07 & 7.95 & 9.58 & 10.98 & 14.56 & 18.36 & 21.16 & 29.58 & 35.33 & 44 \\
\hline Weight & 0.198 & 0.173 & 0.133 & 0.113 & 0.105 & 0.081 & 0.063 & 0.046 & 0.04 & 0.029 & 0.02 \\
$\begin{array}{l}\mu m a x=(4.42 * 0.198)+(6.07 * 0.17 .3)+(7.95 * 0.11 .3)+(10.98 * 0.105)+(14.56 * 0.081)+(18.36 * 0.063)+(21.16 * 0.046)+ \\
(29.58 * 0.04)+\left(35.33^{*} 0.029\right)+(44 * 0.02)=10.36\end{array}$
\end{tabular}

In AHP, all factors are compared pairwise in terms of the intensity of their importance using a continuous 1-9-point scale (Table, 3). This scale enables the decision-maker to incorporate experience and knowledge intuitively (Ladas et al., 2007).

In AHP the importance matrix needs to be analyzed by Eigen value for normalization. To normalize the value, we divide the value by its total column and to calculate weight we consider the mean value of the rows. The most critical threat to landslides is slope, as they are subjected to gravitational force. The second is drainage density as they accelerate erosion process. As the value of the stream density increases, the susceptibility of landslide increase.

Soil texture also plays a vital role in this area for landslide activity. Hence, these are given higher rating, whereas loam and clay loam are less prone to landslide as observed in the field. The LU/LC considered in this study area are dense forest, sparse forest, grass land, bare land, settlement and cultivated area in steep slope area. The landslide occurrence probability value is higher in Barren land, sparse forest, and cultivated land area and lower in dense forest. TWI was classified into five classes and ratings were given in increasing order as TWI value increases. The road construction most often causes slope instability therefore, distance of $50 \mathrm{~m}$ from the road side is considered the most prone to landslide 
activity than the rest of area. The final step is calculating consistency ratio (CR) to consider how the judgment is relatively correct or not. If $\mathrm{CR}>0.1$ our judgment is not accepted and if it is less than 0.1 it is accepted according to Saaty (1980). The CR is calculated as follows:

$$
\begin{aligned}
& \mathrm{CR}=\mathrm{CI}(\text { consistency index }) / \mathrm{RI}(\text { Random consistency index) } \\
& \mathrm{CI}=\mu \max -\mathrm{n}) / \mathrm{n}-1
\end{aligned}
$$

Where

$\mu$ max is the principal Eigen value and $\mathrm{n}$ is the number of parameters employed in our case 10. $\mu$ max is the $\Sigma$ of each weight to multiplied by column total in our case (Table, 4).

Thus $\mathrm{Cl}=(\mu \max -1) / \mathrm{n}-1=(10.39-10) / 10-1$ where $\mathrm{n}$ is number of parameter in our case $10 \mathrm{Cl}=0.064$.

$\mathrm{CR}=\mathrm{Cl} / \mathrm{RI}=0.064 / 1.49=0.042$. Therefore, the $\mathrm{CR}$ is less than 0.1 and the weight of each factor were worked out as next.

\section{Landslide susceptibility mapping}

After AHP pairwise comparison method performed, all factors were combined using the weighted linear combination (WLC) method which is one of the most commonly used in multi-criteria evaluation (Ayalew and Yamagishi,2004). The weights of the factors were linearly combined (WLC) to obtain the landslide susceptible index (LSI) following Mersha and Meten, (2020) as indicated in Eq. 2.

$$
L S I=F R_{1}+F R_{2}+F R_{3} \ldots F R_{n}
$$

Where:

LSI = Landslide susceptibility index

$\mathrm{FR}=$ Frequency ratio

$\mathrm{N}=$ the number of selected causative factors.

Due to the criterion weights being summed to one, the final scores of the combined solution are expressed on the same scale (Feizizadeh and Blaschke 2013). In this case, the higher the factor weight. the more influence on the final landslide susceptibility map (Saaty, 1977). The LSZ map of upper Didessa sub basin is graded into five classes as vary low, low, moderate, high and very high using natural break method of Jenks available in ArcGIS (Figure, 6). ArcMap identifies break points by picking the class breaks that best group similar values and maximize the differences between classes.

\section{Analysis of output LHZ Map}

The landslide distribution results show that $12 \%$ and $6 \%$ of the total land area are high and very high susceptibility to landslide (Table 5). The high hazard zone is found surrounding the areas of moderate and encompass, whereas moderate hazard zones is occurring in the north western, central and north eastern parts of the study area major portions of low hazard zone and very low hazard zones exist in the east to NE and south west parts of the study area part of the study area have clearly indicated moderate to very high susceptibility zones (Figure, 7). 
Table 5

Weighted linear combination landslide susceptibility

distribution results

\begin{tabular}{|llll|}
\hline No & Susceptibility & Area (ha) & Area (\%) \\
\hline 1 & Very low Susceptibility & 34062.23 & 21.6 \\
\hline 2 & Low Susceptibility & 57178.11 & 36.3 \\
\hline 3 & Moderate Susceptibility & 37859.81 & 24 \\
\hline 4 & High Susceptibility & 18892.7 & 12 \\
\hline 5 & Very High & 9446.35 & 6 \\
\hline & Total & 157438.79 & 100 \\
\hline
\end{tabular}

\section{Conclusions}

Landslide is one of the natural environmental disasters that affects environmental health socioeconomic development of all nations in spite of level of economic development. For this study, remote sensing data were obtained from Landsat TM image and DEM of $30 \mathrm{~m}$ resolution, which were used for landslides mapping, geomorphological, hydrological structure and land use change studies. The study evaluated and estimated the landslide hazard based on eleven landslide causative factor i.e., slope, aspect, drainage density, topographic wetness index (TWI), stream power index (SPI), topographic ruggedness index, hypsometric integral, lithology, LULC, soil texture, and distance from road. The research generated a series of landslide susceptibility maps using AHP method. Several causal factors were determined, including: rainfall, slope degree, geology, geomorphology, weathering crust, land cover, lineament density, drainage density, and elevation.

\section{Declarations}

\section{Availability of data and materials:}

Included in the manuscript.

\section{Competing of interest:}

The authors declared no competing interest.

\section{Funding:}

No funding received for this research.

\section{Author contributions:}

RS involved in research design, data collection, data analysis. DOG participated in research design, literature review, data analysis and re-wrote the manuscript to the journal style. KTD actively participate in research design, data analysis and interpretation. All authors read and approved the final manuscript. 


\section{Acknowledgments:}

The authors acknowledge Jimma University College of Social Sciences and Humanities and Jimma University College of Agriculture and Veterinary Medicine for the existing facilities to conduct this research.

\section{References}

1. Ahmed B (2015) Landslide Susceptibility Mapping using Multi-Criteria Evaluation Techniques in Chittagong Metropolitan Area, Bangladesh. Landslide 12:1077-1095.

2. Arca D, Kutoglu HS, Bece K (2018) Landslide susceptibility mapping in an area of underground mining using the multicriteria decision method. Environ. Monit. Assess 190, 725.

3. Ayalew L, Yamagishi H (2004) Slope failures in the Blue Nile basin, as seen from landscape evolution perspective. Geomorphology 57 (1-2):95-116.

4. Basu T, Pal S (2018) RS-GIS based morphometrical and geological multi-criteria approach to the landslide susceptibility mapping in Gish River Basin, West Bengal, India. Adv. Space Res 63(3):1253-1269.

5. Bragagnolo L, da Silva RV, Grzybowski JMV (2020) Landslide susceptibility mapping with r.landslide: A free opensource GIS-integrated tool based on Artificial Neural Networks. Environmental Modelling and Software 123,104565.

6. Carver SJ (1991) Integrating multi-criteria evaluation with geographic information systems. Int. J. Geog. Inf. Syst 5(3):321-339.

7. Chakhar S, Mousseau V (2008) GIS-based multicriteria spatial modeling generic framework. Int. J. Geog. Inf. Sci 22(11):1159-1196.

8. Chen X, Chen W (2021) GIS-based landslide susceptibility assessment using optimized hybrid machine learning methods. Catena 196, 104833.

9. Chen W, Li Y (2020) GIS-based evaluation of landslide susceptibility using hybrid computational intelligence models. Catena 195,104777.

10. Demir G (2019) GIS -based landslide susceptibility mapping for a part of the North Anatolian Fault Zone between Resadiye and Koyulhisar (Turkey). Catena 183,104211.

11. Feizizadeh B, Blaschke T (2013) GIS-multicriteria decision analysis for landslide susceptibility mapping: comparing three methods for the Urmia Lake basin Iran. Nat. Hazard. 65:2105-2128.

12. Feizizadeh B, Roodposhti MS, Jankowski P, Blaschke T (2014) A GIS-based extended fuzzy multi-criteria evaluation for landslide susceptibility mapping. Computers and Geosciences 73:208-221.

13. Hamza T, Raghuvanshi TK (2017) GIS based landslide hazard evaluation and zonation- A case from Jeldu district, Central Ethiopia. J. King Saud Univ Sci 29:151-165.

14. Kamp U, Growley BJ, Khattak GA, Owen LA (2008) GIS-based landslide susceptibility mapping for the 2005 Kashmir earthquake region. Geomorphology 101:631-642.

15. Kayastha P, Dhital MR, Smedt FD (2013) Application of the analytical hierarchy process (AHP) for landslide susceptibility mapping: a case study from the Tinau watershed, west Nepal. Computer and Geoscience 52:398-408.

16. Ladas I, Fountoulis I, Mariolakos I (2007) Using GIS \& multicriteria decision analysis in landslide susceptibility mapping-A case study in Messinia Prefecture area (SW Peloponnesus,Greece). Bulletin of the Geological Society of Greece 40(4):1973-1985.

17. Lombardo L, Opitz T, Ardizzone F, Guzzetti F, Huser R (2020) Space-time landslide predictive modeling. Earth-Science Reviews 209,103318.

18. Maidment DR (eds.) (1992) Handbook of Hydrology. McGraw-Hill, inc. 
19. Mersha T, Meten M (2020) GIS-based landslide susceptibility mapping and assessment using bivariate statistical methods in Simada area, northwestern Ethiopia. Geoenvironmental disasters.7, 20.

20. Moradi M, Bazyar MH, Mohammadi Z (2012) GIS-Based Landslide Susceptibility Mapping by AHP Method, A Case Study, Dena City, Iran. JBASR 2 (7):6715-6723.

21. Nepal N, Chen J, Chen H, Wang X, Shama TPP (2019) Assessment of landslide susceptibility along the Araniko Highway in Poiqu/Bhote Koshi/Sun Koshi Watershed, Nepal Himalaya. Progress in Disaster Science 3, 100037.

22. Nguyen TTN, Liu CC (2019) A new approach using AHP to generate landslide susceptibility maps in the Chen-Yu-Lan Watershed, Taiwan. Sensors 19, 505.

23. Nicu IC, Asandulesei A (2018) GIS-based evaluation of diagnostic areas in landslide susceptibility analysis of Bahluiet River Basin (Moldavian Plateau, NE Romania). Are Neolithic sites in danger? Geomorphology 314:27-41.

24. Nicu IC (2017) Frequency ratio and GIS-based evaluation of landslide susceptibility applied to cultural heritage assessment. Journal of Cultural Heritage 28:172-176.

25. Othman AN, Naim WM, Noraini WM (2012) GIS-based Multi-Criteria Decision Making for Landslide Hazard Zonation. Procedia-Social and Behavioral Sciences 35:595-602.

26. Pradhan AMS, Kim YT (2018) Evaluation of a combined spatial multi-criteria evaluation model and deterministic model for landslide susceptibility mapping. Catena 140:125-139.

27. Raghuvanshi TK, Negassa L, Kala PM (2015) GIS based Grid overlay method versus modeling approach-A comparative study for landslide hazard zonation ( $\mathrm{LHZ})$ in Meta Robi District of West Showa Zone in Ethiopia. EJRS 18:235-250.

28. Saaty TL (1980) The Analytical Hierarchy Process. McGraw Hill, New York.

29. Saaty TL (1977) A scaling method for priorities in hierarchical structures. J. Math. Psychol 15:234-281.

30. Shahabi H, Hashim M (2015) Landslide susceptibility mapping using GIS-based statistical models and remote sensing data in tropical environment. Sci. Rep 5:1-15.

31. Shahri AA, Spross J, Johansson F, Larsson S (2019) Landslide susceptibility hazard map in southwest Sweden using artificial neural network. Catena 183, 104225.

32. Sharma LP, Patel N, Debnath P, Ghose MK (2012) Assessing landslide vulnerability from soil characteristics- a GISbased analysis. Arab J Geosci 5:789-796.

33. Solaimani K, Mousay SZ, Kayian A (2013) Landslide susceptibility mapping based on frequency ration and logistic regression models. Arab. J. Geosci 6, 2557-2569.

34. Subramani T, Krishnan N (2015) Land Slides Hazardous Zones by Using Remote and GIS. IJAIEM 4 (5):211-222.

35. Woldearegay K (2013) Review of the occurrences and influencing factors of landslides in the highlands of Ethiopia. MEJS 5(1):3-31.

36. Yan F, Zhang Q, Ye S, Ren B (2019) A novel hybrid approach for landslide susceptibility mapping integrating analytical process and normalized frequency ratio methods with the cloud model. Geomorphology 327:170-187.

37. Youssef AM, Pourghasemi HR (2020) Landslide susceptibility mapping using machine learning algorithms and comparison of their performance at Abha Basin, Asir Region, Saudi Arabia. Geoscience Frontiers https://soi.org/10.1016/j.gsf.2020.05.010

38. Zhu, AX, Miao Y, Yang L, Bai S, Liu J, Hong H (2018) Comparison of the presence-only method and presence-absence method in landslide susceptibility mapping. Catena 171:222-233.

\section{Figures}




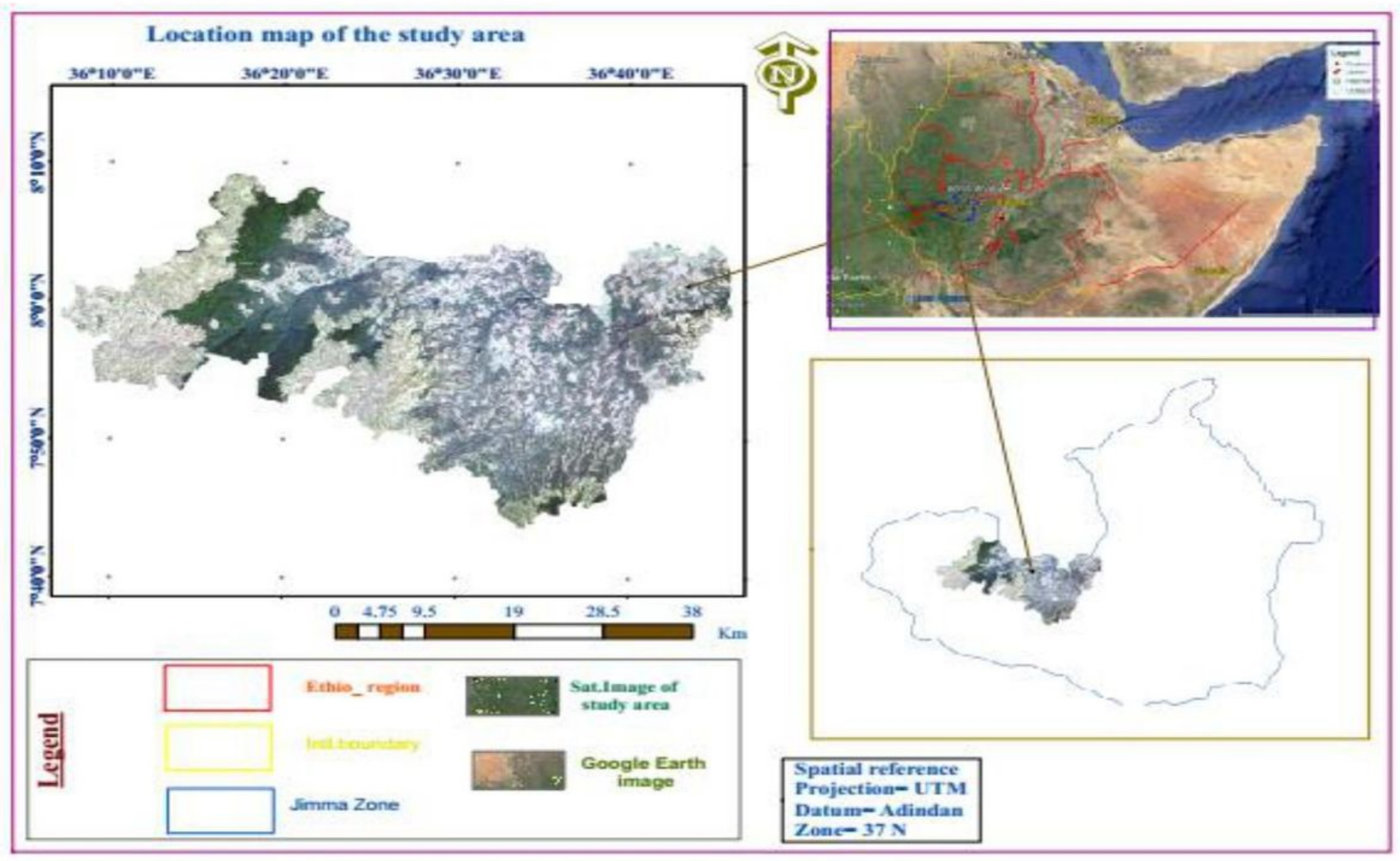

Figure 1

Location map of the study area Note: The designations employed and the presentation of the material on this map do not imply the expression of any opinion whatsoever on the part of Research Square concerning the legal status of any country, territory, city or area or of its authorities, or concerning the delimitation of its frontiers or boundaries. This map has been provided by the authors. 


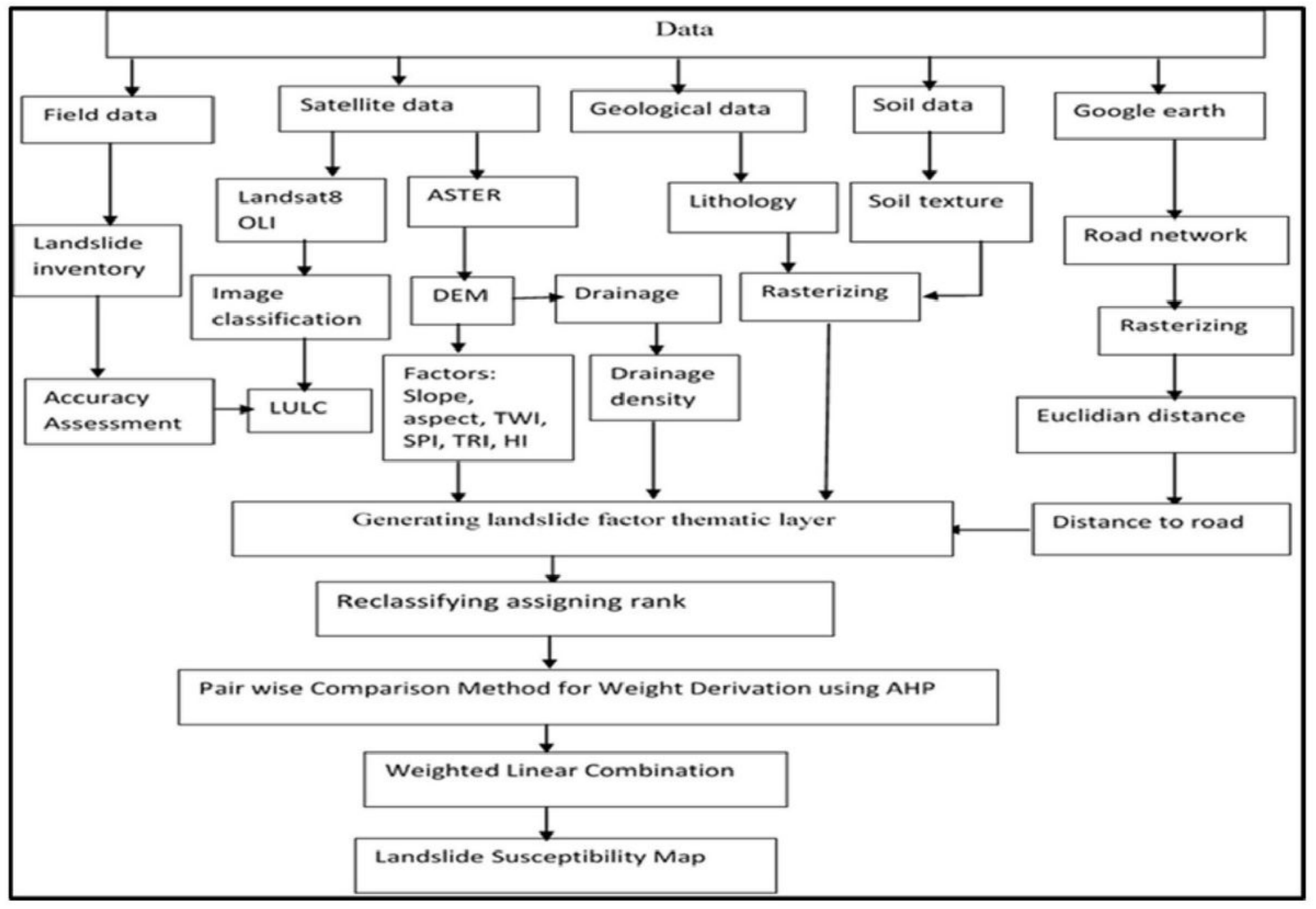

Figure 2

Methodological flowchart
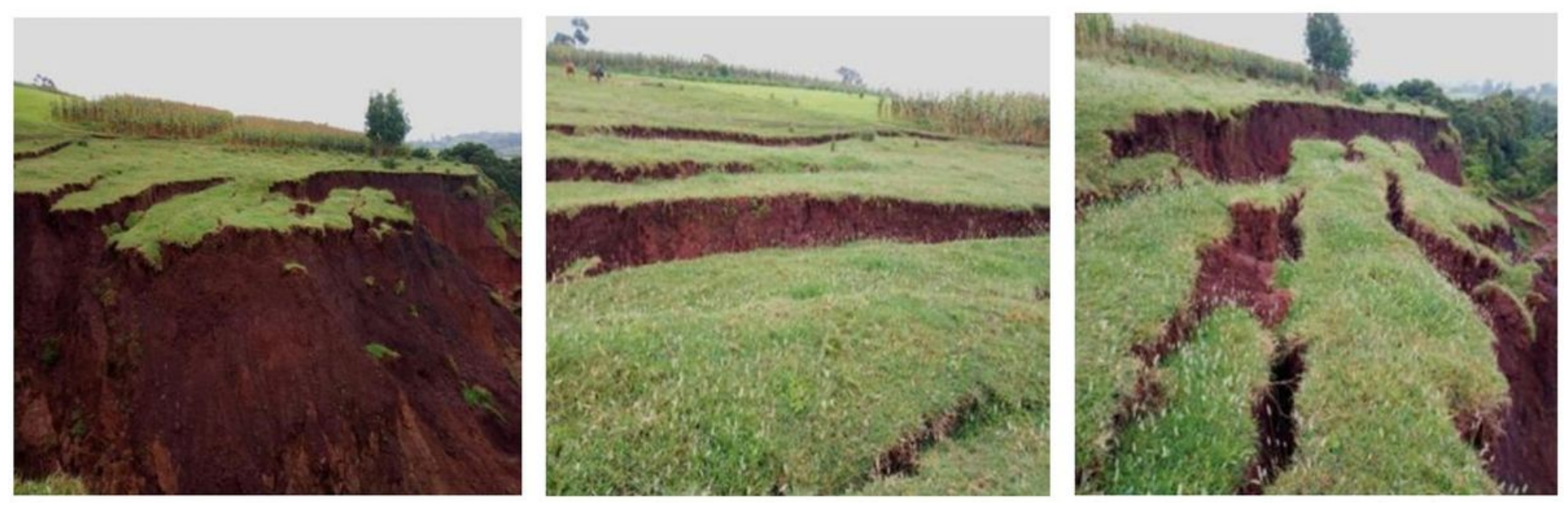

Figure 3

Landslide near crop land at Odo village, Goma district, Jimma Zone (@ Redwan Sultan) 


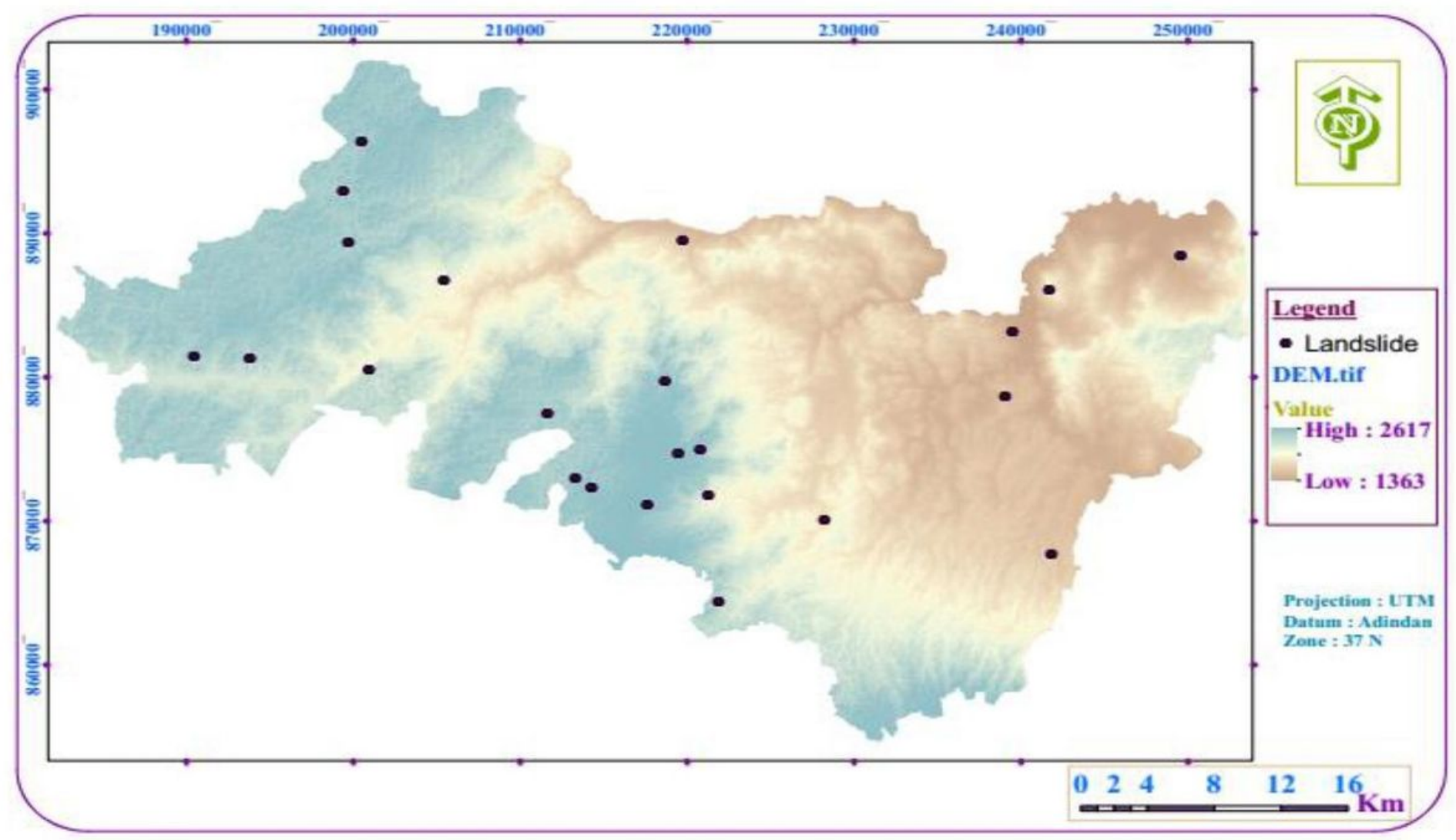

Figure 4

landslide inventory map of the study area Note: The designations employed and the presentation of the material on this map do not imply the expression of any opinion whatsoever on the part of Research Square concerning the legal status of any country, territory, city or area or of its authorities, or concerning the delimitation of its frontiers or boundaries. This map has been provided by the authors. 


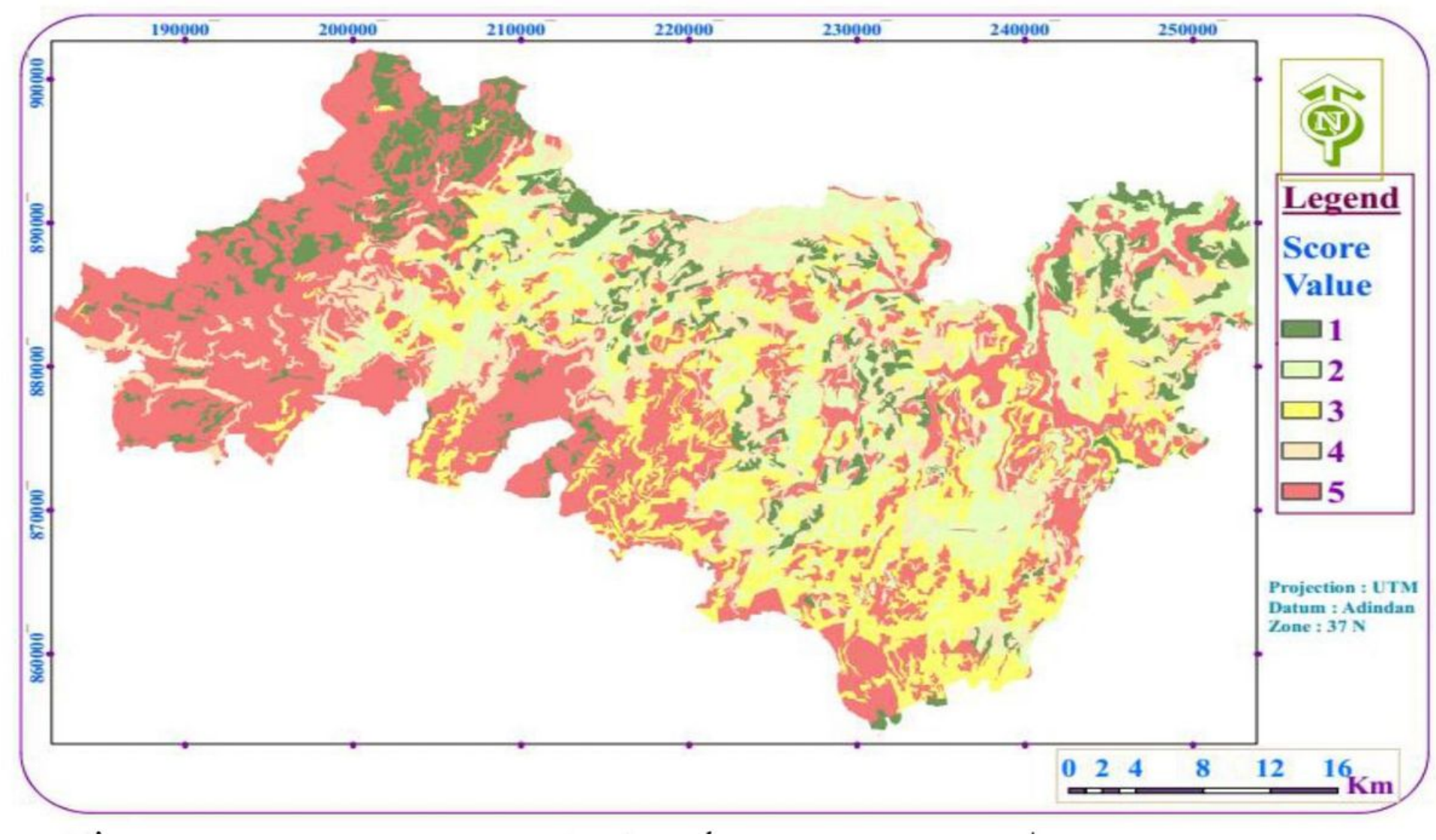

Figure 5

Reclassified soil texture based on assigned rank Note: The designations employed and the presentation of the material on this map do not imply the expression of any opinion whatsoever on the part of Research Square concerning the legal status of any country, territory, city or area or of its authorities, or concerning the delimitation of its frontiers or boundaries. This map has been provided by the authors. 


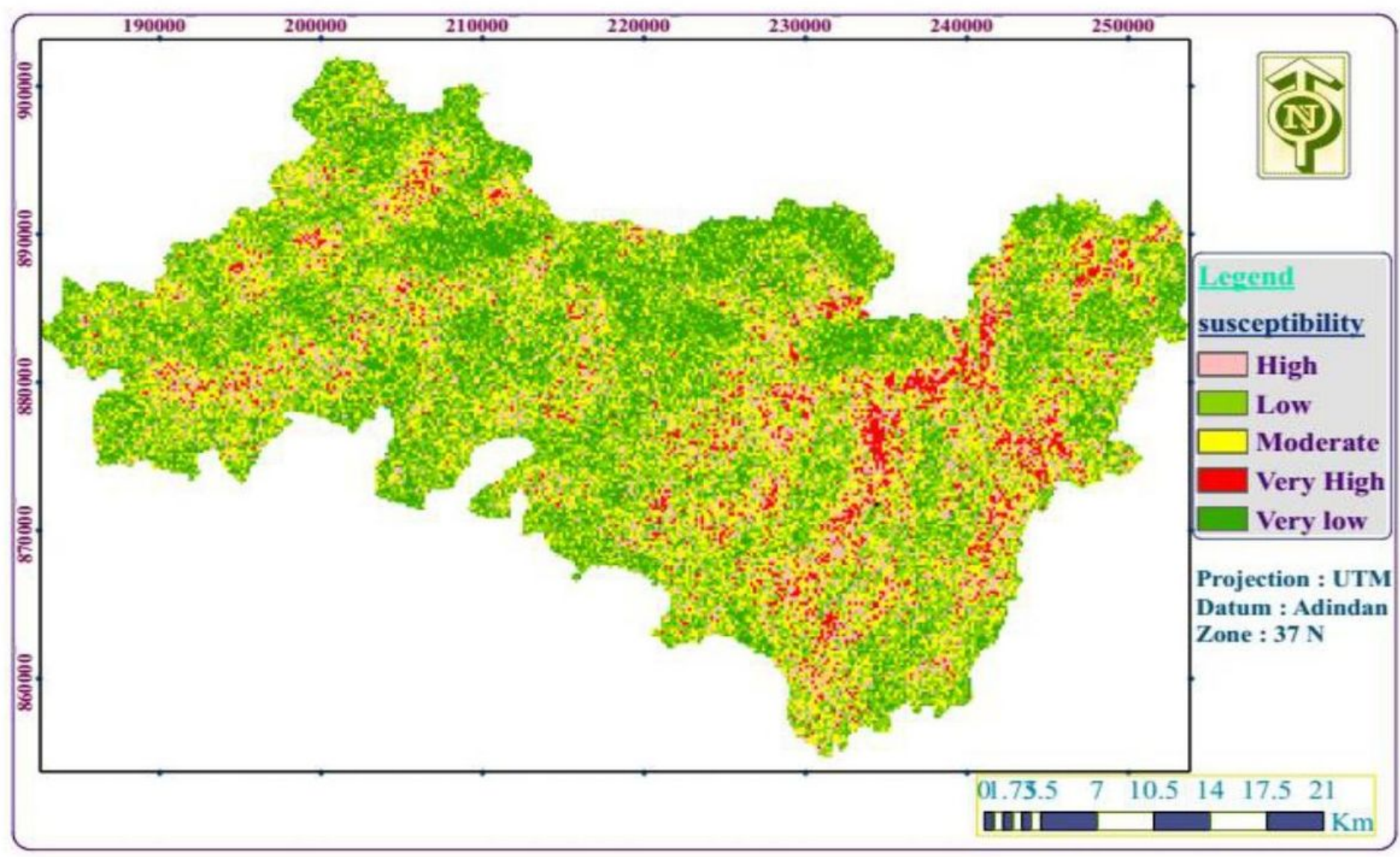

Figure 6

Landslide susceptibility zonation map Note: The designations employed and the presentation of the material on this map do not imply the expression of any opinion whatsoever on the part of Research Square concerning the legal status of any country, territory, city or area or of its authorities, or concerning the delimitation of its frontiers or boundaries. This map has been provided by the authors. 


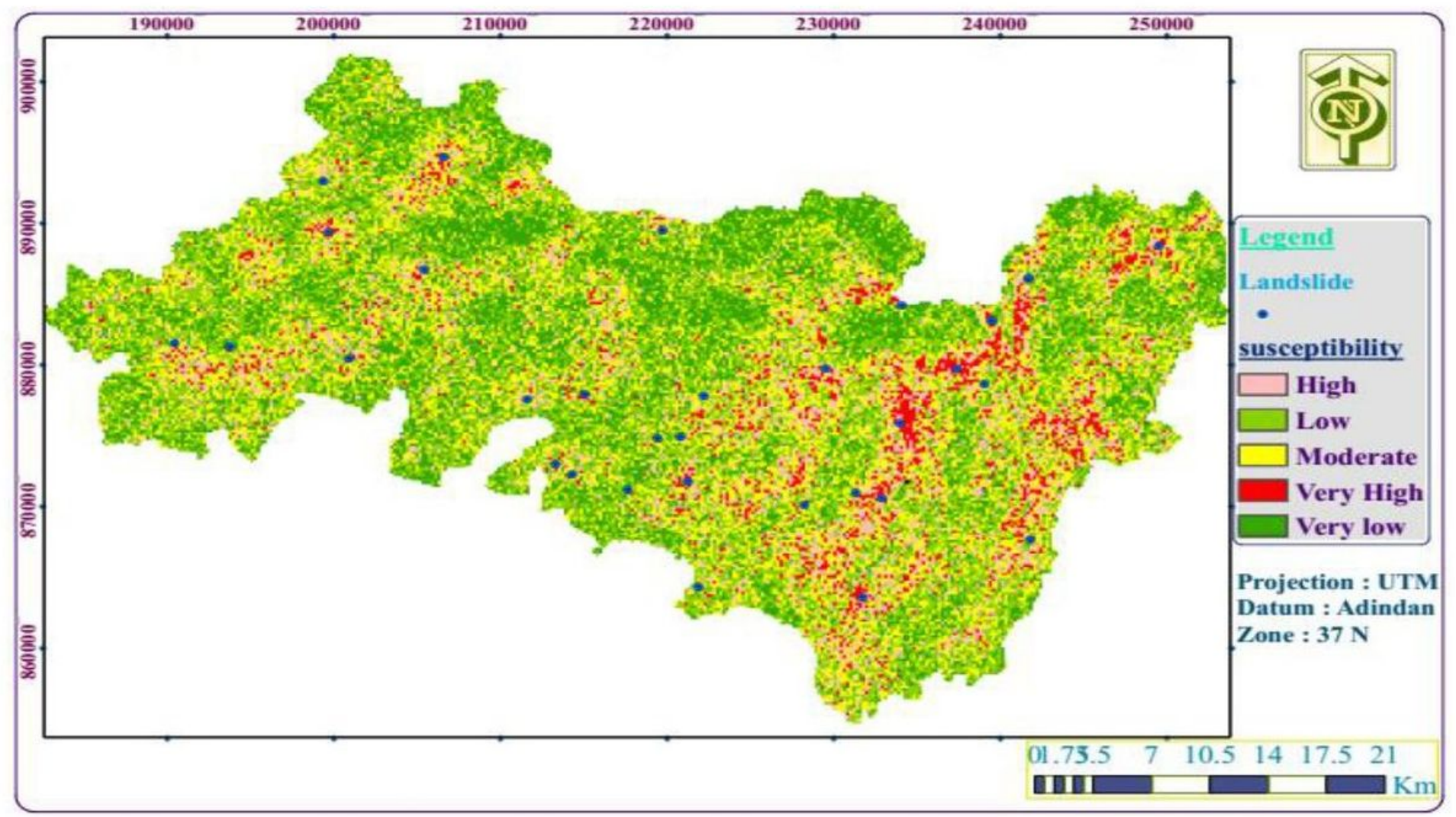

Figure 7

landslide location overplayed with LSM Note: The designations employed and the presentation of the material on this map do not imply the expression of any opinion whatsoever on the part of Research Square concerning the legal status of any country, territory, city or area or of its authorities, or concerning the delimitation of its frontiers or boundaries. This map has been provided by the authors. 